\title{
Kinerja Algoritma Pengenalan Wajah untuk Sistem Penguncian Pintu Otomatis Menggunakan Raspberry-Pi
}

\author{
Raden Budiarto* \\ Sistem Informasi \\ STMIK Jakarta STI\&K, Jakarta \\ *raden@jak-stik.ac.id
}

\begin{abstract}
Abstrak-Pengenalan wajah mampu memberikan pengalaman interaksi yang paling alami, sebagaimana manusia mampu mengenali manusia lain melalui wajah. Implementasi pengenalan wajah memerlukan biaya yang rendah karena tidak memerlukan alat pengenal khusus selain kamera yang pada saat ini sudah tertanam di berbagai perangkat seperti laptop, smartphone, atau tablet. Pengenalan wajah bukan merupakan tugas mudah bagi komputer. Masalah bertambah ketika komputer diharuskan untuk melakukan klasifikasi wajah dengan berbagai situasi dan kondisi seperti pencahayaan yang gelap, dan tangkapan gambar latar belakang yang ada. Artikel ini mendeskripsikan hasil penelitian sistem pengenalan wajah menggunakan Raspberry Pi yang diterapkan untuk sebuah prototipe pengunci pintu. Metode yang digunakan adalah mengambil sampel dataset kemudian mengevaluasi dan membandingkan algoritme pembelajaran untuk dianalisis tingkat keakuratan dan kecepatan dalam mengenali wajah. Pengujian dilakukan untuk menganalisis metode training dataset yang paling baik untuk diimplementasikan berdasarkan kriteria sensitivitas, spesifisitas, dan false rate. Terdapat 4 buah algoritme yang diuji yakni Eigenfaces/PCA dan K-Nearest Neighbor (K-NN), PCA-LDA dan K-NN, Eigenfaces/PCA dan Support Vector Machine (SVM), PCA-LDA, dan SVM. Hasil penelitian menunjukkan algoritme hybrid Eigen-Fisherfaces (PCA-LDA) dan k-nearest neighbor adalah yang metode yang paling akurat untuk pengenalan wajah. Akurasi mendekati 100\% dapat diperoleh dengan perhitungan machine learning dengan 4 fold.
\end{abstract}

Kata Kunci: Pengenalan wajah, machine learning, raspberry, eigen fisherfaces, k-nearest neighbor

\section{Pendahuluan}

Selama beberapa tahun terakhir, ada banyak sekali pilihan pada teknologi konvensional dan teknologi biometri untuk memenuhi kebutuhan keamanan untuk rumah tangga atau kantor. Beberapa sistem keamanan konvensional, contohnya menggunakan kunci, passcode, kartu ID, dan/atau kartu RFID, bisa jadi tidak dapat diandalkan apabila benda untuk akses tersebut dicuri atau hilang. Sistem keamanan seperti itu memiliki kekurangan ketika akses tersebut dicuri oleh orang yang tidak memiliki wewenang untuk mendapatkan akses [1]. Oleh karena itu, sistem keamanan biometri dianggap sebagai salah satu metode autentikasi yang paling aman, sehingga dapat memberikan tingkat keamanan yang lebih baik dibandingkan dengan sistem keamanan konvensional [2].

Fingerprint recognition atau pengenalan sidik jari menjadi metode paling populer dalam teknologi biometri. Metode populer lainnya adalah pengenalan suara, pengenalan tanda tangan, pemindaian iris, dan pemindaian retina [3]. Metode-metode tersebut memberikan tingkat nilai keamanan yang sama karena menggunakan identitas unik pada manusia. Akan tetapi, dalam implementasinya metode-metode tersebut tidak dapat mengalahkan metode pengenalan wajah dalam aspek kenyamanan. Face recognition atau pengenalan wajah mampu memberikan pengalaman interaksi yang paling alami, hal yang serupa ketika manusia mampu mengenali manusia lain melalui wajah. Hal positif lain dalam implementasi pengenalan wajah juga akan mengurangi biaya karena tidak memerlukan alat pengenal khusus selain kamera yang biasanya menjadi perangkat umum pada komputer. Akan tetapi, implementasi sistem dalam mengenali wajah harus dirancang dengan baik dan akurat agar sifat alami yang diberikan metode pengenalan wajah bisa dimanfaatkan dengan maksimal.

Berbeda dengan pengenalan wajah manusia yang mudah dilakukan setiap saat oleh manusia, bagi komputer pengenalan fitur wajah manusia adalah sebuah tugas yang sulit. Masalah ini timbul karena komputer diharuskan untuk melakukan klasifikasi wajah dengan benar dengan berbagai situasi dan kondisi seperti pencahayaan yang gelap, dan tangkapan gambar latar belakang yang ada [4]. Sampai ini algoritme pengenal wajah masih menjadi topik penelitian yang menarik dan terus berkembang. Pada umumnya cara komputer merepresentasikan wajah dibagi dalam dua metode pendekatan [5] sebagaimana dijabarkan dalam tabel 1.

Perancangan sistem menggunakan Raspberry Pi 3 Model B untuk mekanisme kunci pintu dengan pengenalan wajah. Alasan utama menggunakan Raspberry Pi adalah portabilitasnya, selain dari faktor harga yang murah yang menjadi suatu kelebihan bagi pengguna sistem ini [6]. Perangkat Raspberry Pi populer untuk berbagai aplikasi sistem tertanam dan aplikasi Internet of Things (Io'T). 
Tabel 1. Pendekatan representasi gambar wajah

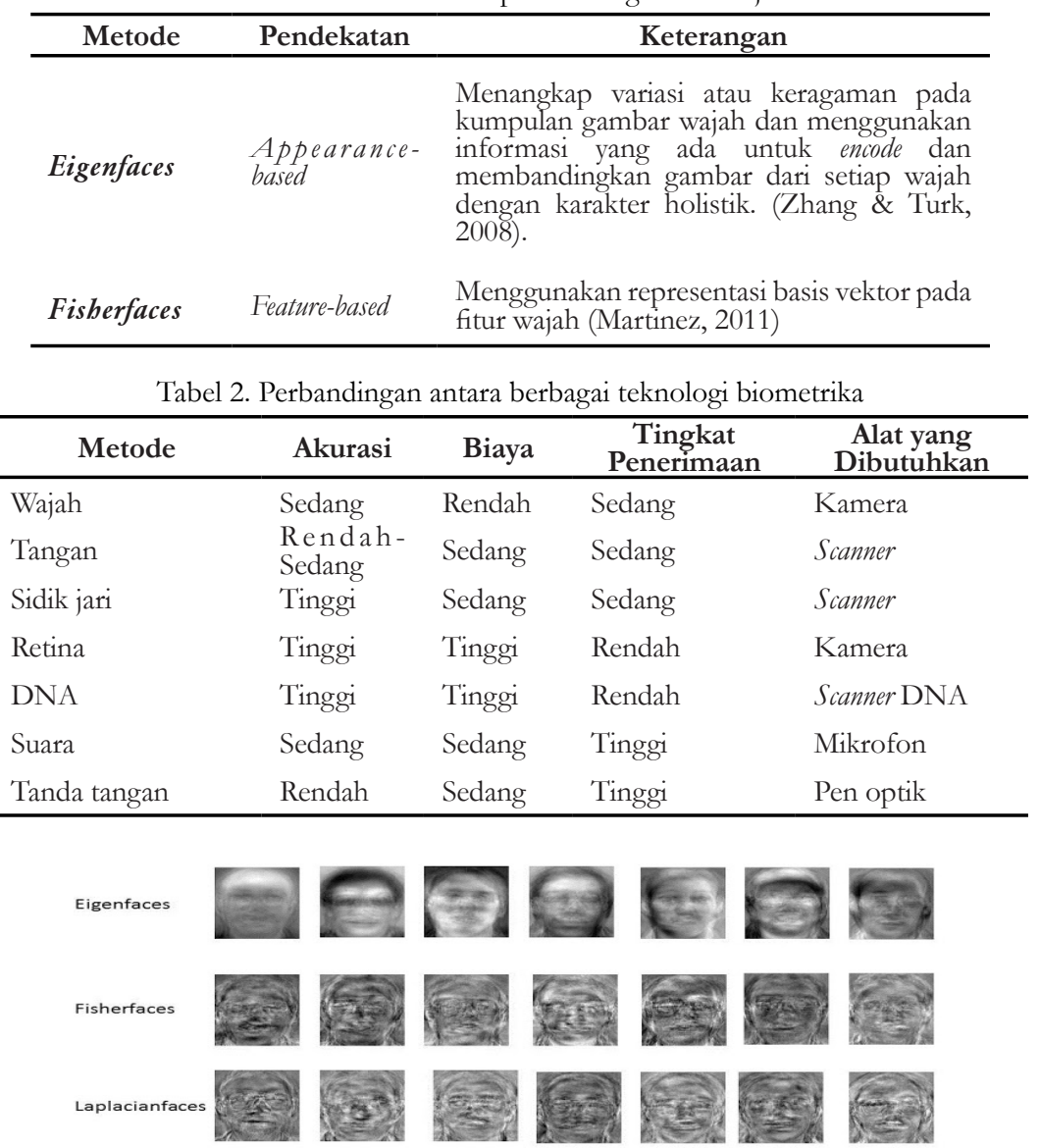

Gambar 1. Perbandingan rekonstruksi wajah metode eigenfaces dan fisherfaces

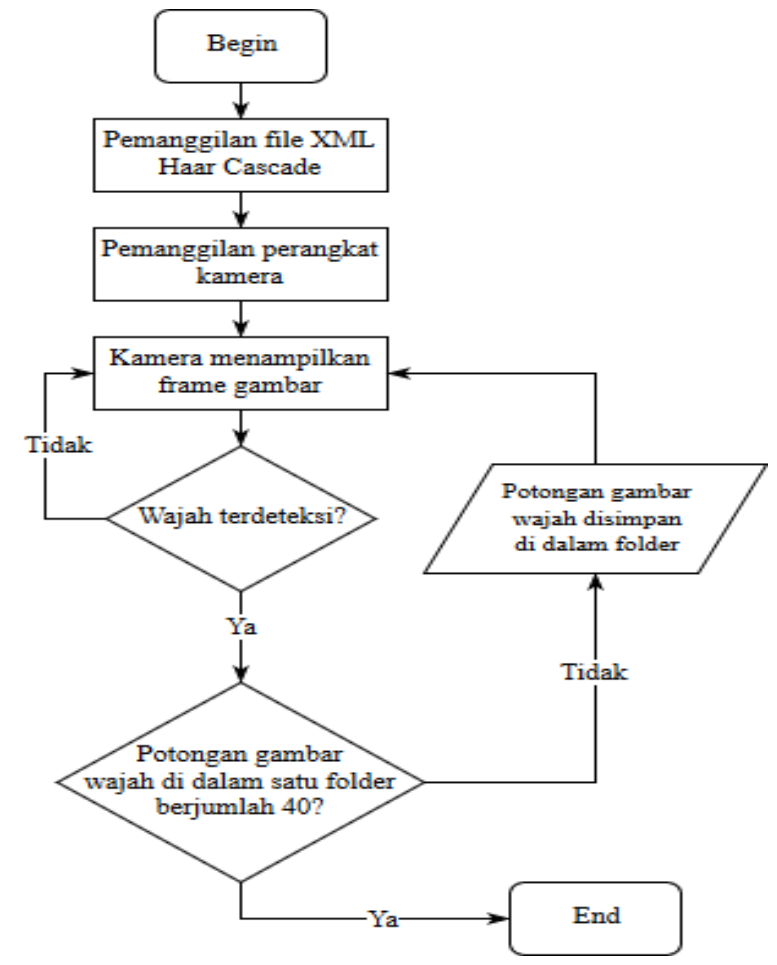

Gambar 2. Flowchart aplikasi pengambilan dataset wajah 


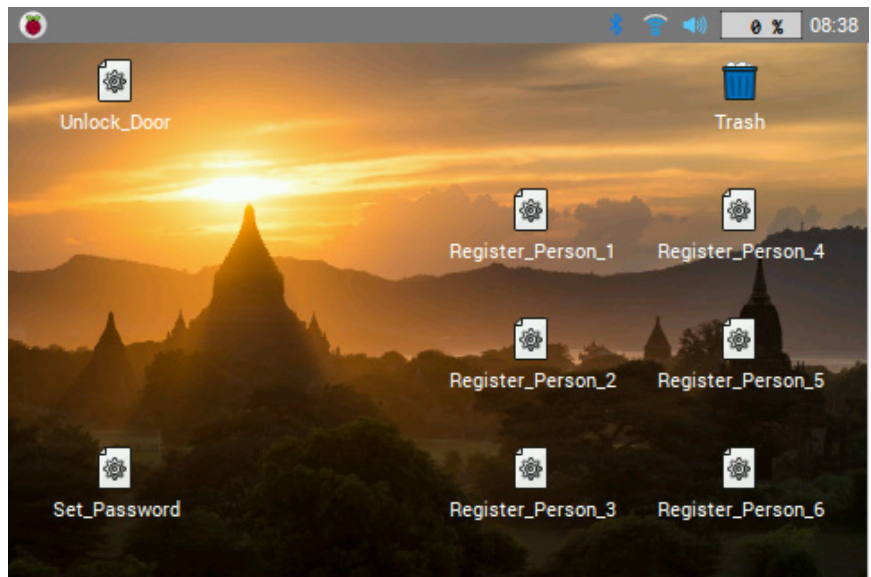

Gambar 3. Tampilan antarmuka sistem penguncian pintu dengan metode pengenalan wajah

Raspberry Pi memiliki konsumsi daya CPU dan GPU yang rendah, yang sekaligus memiliki nilai kelebihan dan kekurangan.

Dengan spesifikasi tegangan dan arus input yang disarankan sebesar 5V/2.5A (Raspberry, n.d.), Raspberry Pi 3 Model B bisa dikatakan low voltage. Raspberry Pi 3 Model $\mathrm{B}$ juga dapat bekerja dengan baik pada tegangan dan arus input $5 \mathrm{~V} / 2 \mathrm{~A}$, sehingga dapat menggunakan power bank sebagai sumber tegangan eksternal. Kesimpulan awalnya, kebutuhan power yang rendah akan berdampak pada performa yang biasanya buruk, akan tetapi cukupan apabila mengingat harganya yang murah.

Berdasarkan uraian latar belakang masalah tersebut maka tujuan penelitian ini adalah untuk menguji berbagai kombinasi dari algoritme deteksi wajah berdasarkan kriteria sensitivitas, spesifisitas, dan false rate. Batasan penelitian yang ditetapkan adalah terkait metode kombinasi algoritme yang diuji yakni Eigenfaces/PCA dan K-Nearest Neighbor (K-NN), PCA-LDA dan K-NN, Eigenfaces/PCA dan Support Vector Machine (SVM), PCA-LDA dan SVM. Batasan juga ditetapkan pada implementasi pengujian hanya pada sistem Raspberry Pi 3. Luaran dari penelitian ini diharapkan dapat menghasilkan rancangan prototipe sistem keamanan kunci pintu dengan implementasi teknologi pengenalan wajah. Selain itu kontribusi teori yang diharapkan adalah untuk menemukan metode pengenalan wajah yang efektif dan efisien sesuai dengan performa Raspberry Pi 3.

\section{Tinjauan Pustaka}

Untuk melakukan penelitian mengenai bagaimana perancangan sistem keamanan rumah tangga menggunakan implementasi teknologi pengenalan wajah, saat ini terdapat berbagai penelitian serupa. Di antaranya penelitian yang dimuat di dalam makalah yang berjudul Real Time Access Control Based on Face Recognition [7] Penelitian ini dilakukan oleh Ylber Januzaj, Artan Luma, Ymer Januzaj, dan Vehbi Januzaj dari South East European University pada tahun 2015. Tujuan dari penelitian ini adalah menyediakan sistem keamanan akses yang mengontrol orang keluar dan masuk dari berbagai gedung menggunakan magnetic lock, sesuai dengan permintaan yang ada. Pada makalahnya, Januzaj membahas landasan teori tentang tiga metode yang dapat digunakan untuk membuka akses pintu, yaitu metode akses menggunakan kata kunci, akses menggunakan RFID, dan akses menggunakan teknologi biometri. Bagaimana celah pada penelitian-penelitian sebelum adalah kurangnya uji analisis perbandingan gabungan algoritme dan cenderung hanya menguji satu atau masing-masing algoritme.

Setiap manusia memiliki identitas bawaan yang sifatnya unik, oleh karena itu sistem keamanan yang berbasis biometri sangat dianjurkan untuk digunakan di dalam lingkungan yang membutuhkan tingkat keamanan yang tinggi. Teknologi biometri adalah teknologi yang paling aman digunakan karena fitur-fitur pada manusia seperti wajah, jari, dan suara tidak bisa dipinjamkan atau dicuri. [8]. Berdasarkan riset yang telah dilakukan oleh mereka, sejumlah empat faktor yang menjadi perbandingan pada beberapa sistem keamanan berbasis teknologi biometri ini yaitu akurasi, biaya, tingkat penerimaan, dan peralatan yang dibutuhkan, dijelaskan ke dalam tabel 2 .

Tabel 2 menjelaskan perbandingan antara berbagai teknologi biometri, penggunaan metode pengenalan wajah memiliki tingkat akurasi yang sedang apabila dibandingkan dengan metode lainnya. Akan tetapi, tingkat akurasi yang sedang tersebut bisa ditingkatkan dengan cara memperbaiki kondisi lingkungan sekitar agar menjadi lebih kondusif, contohnya pencahayaan. Dibandingkan dengan beberapa metode lain, penggunaan metode pengenalan wajah juga murah dalam segi biaya. Biaya yang murah untuk metode pengenalan wajah disebabkan oleh kesederhanaan dari alat yang dibutuhkan, yaitu kamera. Saat penelitian ini ditulis, harga modul kamera untuk Raspberry Pi relatif murah dibandingkan alat lainnya, yaitu berkisar antara Rp300.000 sampai dengan Rp400.000. Faktor terakhir tentang perbandingan antara teknologi biometri adalah tingkat penerimaan, yang mana metode pengenalan wajah memiliki tingkat penerimaan sedang [9]. Untuk meningkatkan keamanan dari sistem, maka diperlukan penyetelan agar dapat mengurangi tingkat penerimaan tersebut.

Pengenalan wajah mengidentifikasi beberapa fitur wajah dengan mengekstrak fitur pada gambar yang menampilkan wajah subjek. Contohnya, sebuah algoritme yang menganalisis posisi, bentuk, atau ukuran dari mata, hidung, bibir, dan dagu. Hasil dari pengukurannya disimpan ke dalam dataset dan menghasilkan facial metrics [10]. Fitur ini yang akan digunakan untuk template matching pada teknik konvensional. Teknik konvensional seperti 
template matching adalah satu dari beberapa sistem yang banyak diterapkan untuk metode pengenalan wajah (gambar 3).

Template matching pada teknik pengenalan wajah adalah proses pencarian lokasi dari fitur-fitur wajah yang penting dan menonjol dan urutan representasi dari wajah. Template matching menjadi salah satu teknik yang esensial digunakan dalam aplikasi analisis gambar [11]. Di dalam implementasi template matching, fitur wajah yang sudah diekstrak dibandingkan dengan data yang sudah disimpan untuk pengenalan wajah. Akan tetapi, penggunaan template matching untuk pengenalan wajah hanya cocok untuk kondisi lingkungan yang stabil. Template matching sederhana tidak akan mampu mengenali wajah pada tingkat perubahan cahaya yang signifikan. Oleh karena itu, demi meningkatkan akurasi sistem pada proses pengenalan wajah maka diperlukan metode lain yang dapat membaca garis-garis wajah yang dideteksi dengan lebih baik.

Metode eigenfaces dipengaruhi oleh teknik yang dinamakan principal component analysis (PCA) untuk merepresentasikan gambar wajah secara efisien. Pada kumpulan gambar wajah yang tersedia, PCA menghitung sistem koordinat terbaik untuk kompresi gambar, di mana setiap koordinat adalah gambar yang disebut eigenpicture. Sirovich dan Kirby [12] menyatakan bahwa di dalam prinsip ini setiap koleksi gambar wajah dapat direkonstruksi dengan cara menyimpan koleksi kecil dari berat nilai setiap gambar dan set kecil dari gambar standar (eigenpicture). Berat nilai yang menggambarkan setiap wajah ditemukan dengan memproyeksikan gambar wajah ke dalam setiap eigenpicture.

Berbeda dengan eigenfaces yang menggunakan teknik principal component analysis (PCA), metode fisherfaces menggunakan model proyeksi linier yang diskriminan atau biasa disebut linear discriminant analysis (LDA). Metode fisherfaces ini pertama kali diajukan oleh Belheumur et al. [13] yang telah mereka dibuktikan bahwa implementasi metode ini mampu mengurangi error rate yang dihasilkan oleh metode eigenfaces pada lingkungan eksperimen yang sama. LDA memaksimalkan rasio antar kelas dengan penyebaran di dalam kelas, oleh karena itu, fisherfaces bekerja lebih baik daripada PCA pada eigenfaces untuk tujuan diskriminasi. Implementasi fisherfaces sangat berguna saat gambar wajah memiliki variasi pencahayaan dan ekspresi wajah yang besar. Perbedaan hasil rekonstruksi citra wajah kedua algoritme ini ditunjukkan pada gambar 1.

\section{Metodologi}

Jenis penelitian yang digunakan adalah penelitian kuantitatif yakni penelitian yang digunakan untuk meneliti pada populasi atau sampel tertentu, pengumpulan data menggunakan instrumen penelitian, analisis data bersifat statistik, dengan tujuan untuk menguji hipotesis yang telah ditetapkan [14]. Penelitian ini tergolong jenis penelitian kuantitatif karena data penelitian berupa angka-angka dan analisis menggunakan statistik yang diuji terukur melalui percobaan empiris. Pengumpulan data dalam penelitian ini dilakukan dengan studi literatur berupa mengumpulkan pembahasan jurnal, atau makalah yang ada kaitannya dengan judul penelitian dan observasi dengan mengadakan penelitian dan peninjauan langsung terhadap permasalahan yang diambil.

Metode pengukuran efisiensi dan efektivitas algoritme yang digunakan adalah teknik cross-validation yang merupakan metode statistik untuk mengevaluasi dan membandingkan algoritme pembelajaran dengan membagi data menjadi dua segmen: satu digunakan untuk belajar atau melatih model dan yang lainnya digunakan untuk memvalidasi model. [15]. Cross-validation digunakan untuk mengevaluasi atau membandingkan algoritme pembelajaran sebagai berikut: pada setiap iterasi, satu algoritme learning atau yang lain menggunakan data $\mathrm{k}-1$ untuk mempelajari satu model atau lebih, dan selanjutnya model yang dipelajari diminta untuk membuat prediksi tentang data di dalam validation fold. Performa setiap algoritme learning pada setiap fold dapat dilacak dengan menggunakan beberapa performance metric yang telah ditentukan seperti akurasi. Setelah selesai, sampel k dari performance metric akan tersedia untuk setiap algoritme.

Dalam validasi silang $\mathrm{k}$-fold, data dipartisi terlebih dahulu menjadi segmen atau lipatan berukuran sama (atau hampir sama). Selanjutnya iterasi $\mathrm{k}$ pada training dan validasi dilakukan sedemikian rupa sehingga dalam setiap iterasi data yang berbeda dilangsungkan untuk proses pengetesan, sedangkan fold sisanya $\mathrm{k}-1$ akan digunakan untuk proses training. Data biasanya berupa data bertingkat sebelum dipecah menjadi k-fold. Setelah itu dilakukan proses penyusunan ulang data untuk memastikan setiap fold merupakan hasil representasi yang baik dari keseluruhan. Sebagai contoh, pengaturan $k=2$ akan menghasilkan 2-fold cross-validation. Pada 2 -fold crossvalidation, secara acak dataset dibagi menjadi dua yaitu $d_{0}$ and $d_{1}$, sehingga kedua set memiliki ukuran yang sama. Setelah itu, $d_{0}$ dan $d_{1}$ masing-masing dites, lalu diikuti dengan melakukan training pada $d_{1}$ dan testing pada $d_{0}$. Ketika $k=n$ (jumlah observasinya), k-fold cross-validation yang dipakai akan sama dengan leave-one-out cross-validation.

Untuk program pengambilan dataset wajah, ada tiga proses yang dijalankan. Yang pertama, program melakukan pemanggilan file XML Haar Cascade versi alternatif kedua yang dinamakan haarcascade_frontalface_alt2. $\mathrm{xml}$ secara default. Kedua, program akan melakukan pemanggilan perangkat kamera (RPi kamera pada Raspberry Pi). Ketiga, kamera menampilkan frame gambar dengan rate 30 frame per detik (fps). Ketika program mendeteksi ada wajah di dalam frame gambar, maka potongan wajah yang ditangkap oleh XML disimpan di dalam folder sebagai dataset wajah untuk training. Apabila jumlah potongan gambar wajah yang sudah tersimpan mencapai 40 buah, maka program diinstruksikan untuk berhenti mengambil dan menyimpan potongan gambar wajah. Proses ini dijelaskan dalam flowchart pada Gambar 2.

Ada tujuan di balik pembatasan jumlah potongan gambar wajah yang disimpan ke dalam dataset yang hanya sejumlah 40 buah per folder (atau per orang). Dataset wajah yang digunakan di dalam sistem penguncian pintu berbasis metode pengenalan wajah terdiri dari 40 folder untuk sampel wajah true negative yang diambil dari AT\&T Faces Database di mana masing-masing sampel wajah terdiri dari 40 potongan gambar, dan 6 folder untuk sampel wajah true positive. Potongan gambar wajah untuk sampel wajah true positive yang disimpan melalui program berjumlah 40 buah akan mengurangi gejala underfitting atau overfitting karena memiliki bobot yang setara dan masuk akal dengan sampel wajah true negative yang digunakan. Gejala underfitting atau overfitting akibat perbedaan jumlah sampel akan memperburuk tingkat keyakinan sistem dalam melakukan pengenalan wajah. 


\begin{tabular}{|c|c|c|c|c|c|c|c|c|c|c|c|c|}
\hline & 00 & 01 & 02 & & 00 & 01 & 02 & & & $\mathrm{oO}$ & 01 & 02 \\
\hline co & A & B & B I & $\mathrm{cO}$ & I B & A & B I & c0 & 1 & B & B & A I \\
\hline & H & B & B & c1 & B & A & B I & c1 & & B & B & A I \\
\hline & A & B & & $c 2$ & B & A & B I & c2 & & B & B & A \\
\hline
\end{tabular}

Gambar 4. Teknik matrix cross validation

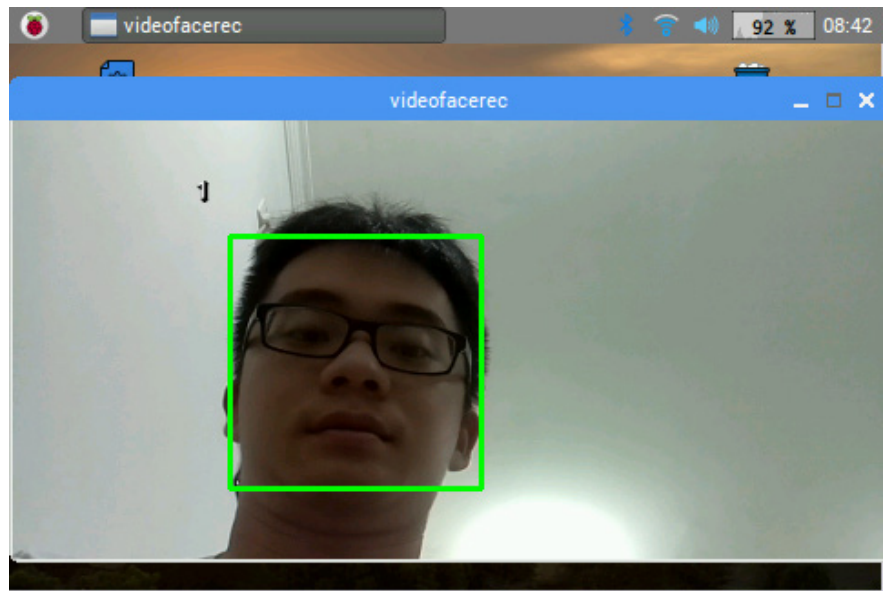

Gambar 5. Tampilan program pengenalan wajah saat membuka kunci pintu

Pembuatan antarmuka sistem untuk masing-masing pilihan menu menggunakan Bash shell yang diletakkan pada desktop Raspbian Jessie. Bash sendiri merupakan nama bahasa pemrograman pada Linux yang fungsinya sebagai shell, yaitu memberikan urutan perintah kepada terminal dan perintah tersebut dieksekusi. Gambar tampilan antar muka program ditunjukkan dengan gambar 3 .

Ada beberapa alasan yang kuat mengapa Bash diimplementasikan untuk antarmuka sistem [16]. Yang pertama adalah menampilkan pilihan menu secara instan ketika perangkat Raspberry Pi dinyalakan. Kedua, Bash tidak akan membebani prosesor sehingga tidak mempengaruhi kinerja program pengenalan wajah secara keseluruhan. Ketiga, Bash sangat mudah untuk dibuat. Cara untuk membuat file Bash adalah membuat file baru yang kosong, edit file tersebut menggunakan text editor, dan kemudian memasukkan command yang ingin dieksekusi apabila file Bash tersebut dijalankan. File kosong akan otomatis menjadi file Bash ketika di baris 1 (gambar 4).

Untuk program pengenalan wajah, ada tiga proses tugas machine learning yang harus dilakukan oleh sebuah perangkat keras atau komputer dalam implementasinya melakukan training pengenalan wajah.

Yang pertama adalah pengenalan terhadap fitur wajah yang diambil dari dataset menggunakan teknik PCA atau perpaduan antara teknik PCA dan LDA. PCA sendiri digunakan untuk memperkirakan fitur dataset wajah ke dalam fitur vector yang memiliki dimensional yang lebih rendah. Di dalam perpaduan implementasi antara PCA dan LDA, metode ini terbagi ke dalam dua langkah yaitu memproyeksikan gambar wajah dari ruang vector asli ke subspace dengan PCA, kemudian menggunakan LDA untuk mendapatkan linear classifier terbaik. Ide konsep untuk memadukan PCA dan LDA adalah untuk meningkatkan kemampuan generalisasi LDA apabila hanya tersedia sedikit sampel per satu class. Di sisi lain, LDA meningkatkan nilai diskriminan dari fitur PCA.

Yang kedua, melakukan pengklasifikasian dataset wajah menggunakan metode classifier yang dianggap cocok untuk sistem ini, yaitu k-nearest neighbor dan support vector machine. Keduanya memiliki representasi yang berbeda pada pendekatan dalam proses learning. K-nearest neighbor berusaha untuk memperkirakan distribusi data yang mendasarinya secara non-parametrik, sedangkan SVM mengasumsikan ada byperplane yang memisahkan titik data, yang merupakan asumsi yang cukup ketat. Yang terakhir, proses verifikasi pengenalan wajah diakhiri dengan validasi data menggunakan $\mathrm{k}$-fold cross validation. Cara kerja validasi data yang ditugaskan kepada metode $\mathrm{k}$-fold cross validation adalah sebagai berikut:

Data yang sudah melewati tahap pengenalan fitur dan klasifikasi, k-fold cross validation membagi data tersebut menjadi fold atau lipatan sebanyak $k$ yang besarnya sama dan tidak overlapping untuk proses training dan testing. Sebagai contoh, pada gambar 4 merupakan 3-fold cross validation untuk 9 data observasi and 3 class, sehingga setiap observasi diberikan index [c_i] $\left[\mathrm{o} \_\mathrm{i}\right]$ seperti pada gambar 4.

Model dari hasil training dataset wajah disimpan ke dalam file pickle. Pickle sendiri merupakan sebuah modul Python untuk serialisasi data, yang mana akan mengubah objek dataset wajah menjadi sebuah file byte stream. Objek dataset wajah tersebut pada dasarnya adalah sebuah classifier dari machine learning yang harus dipanggil setiap kali menjalankan program. Fungsi pickle di dalam program pengenalan wajah ini adalah menyimpan objek dataset wajah dalam format ekstensi (*.pkl) sehingga sistem hanya memerlukan satu kali proses training dan setelahnya file pickle dapat dipanggil tanpa perlu mengulang proses training yang membutuhkan waktu relatif lama.

Proses training selesai setelah melalui tahap pengenalan fitur, klasifikasi, dan validasi data wajah. File pickle yang sudah disimpan dapat langsung digunakan untuk program pembuka pintu, yang mengakibatkan waktu yang dibutuhkan untuk peluncuran program menjadi instan. Program dianggap sudah berjalan ketika keberadaan perangkat RPi kamera berhasil dideteksi dan kamera mampu menampilkan frame gambar sebanyak 30 frame per detik (fps). 
Tabel 3 Hasil pengukuran sensitivitas

\begin{tabular}{ccccc}
\hline $\begin{array}{c}\text { Nilai } \\
\text { k-fold }\end{array}$ & $\begin{array}{c}P C A, \\
k N N\end{array}$ & $\begin{array}{c}P C A- \\
\text { LDA, } \\
k N N\end{array}$ & $\begin{array}{c}P C A, \\
\boldsymbol{S} V M\end{array}$ & $\begin{array}{c}P C A- \\
\text { LDA, } \\
\boldsymbol{S} V M\end{array}$ \\
\hline 10-fold & $40(1)$ & $40(1)$ & $40(1)$ & $40(1)$ \\
8-fold & $40(1)$ & $40(1)$ & $40(1)$ & $40(1)$ \\
6-fold & $40(1)$ & $40(1)$ & $40(1)$ & $39(0.975)$ \\
5-fold & $40(1)$ & $40(1)$ & $39(0.975)$ & $39(0.975)$ \\
4-fold & $39(0.975)$ & $39(0.975)$ & $39(0.975)$ & $39(0.975)$ \\
3-fold & $39(0.975)$ & $39(0.975)$ & $38(0.95)$ & $37(0.925)$ \\
2-fold & $36(0.9)$ & $36(0.9)$ & $36(0.9)$ & $36(0.9)$ \\
\hline
\end{tabular}

Tabel 4 Hasil uji spesifisitas

\begin{tabular}{|c|c|c|c|c|}
\hline $\begin{array}{l}\text { Nilai } \\
\text { k-fold }\end{array}$ & $\begin{array}{l}P C A, \\
k N N\end{array}$ & $\begin{array}{l}P C A- \\
L D A, \\
k N N\end{array}$ & $\begin{array}{l}P C A, \\
S V M\end{array}$ & $\begin{array}{l}P C A- \\
L D A, \\
S V M \\
\end{array}$ \\
\hline $\begin{array}{l}10- \\
\text { fold }\end{array}$ & $1600(1)$ & $\begin{array}{c}1578 \\
(0.986)\end{array}$ & $1600(1)$ & $\begin{array}{c}1571 \\
(0.982)\end{array}$ \\
\hline 8-fold & $\begin{array}{c}1591 \\
(0.994)\end{array}$ & $\begin{array}{c}1567 \\
(0.979)\end{array}$ & $1600(1)$ & $\begin{array}{c}1569 \\
(0.981)\end{array}$ \\
\hline 6-fold & $1600(1)$ & $\begin{array}{c}1574 \\
(0.984)\end{array}$ & $\begin{array}{c}1583 \\
(0.989)\end{array}$ & $\begin{array}{c}1547 \\
(0.967)\end{array}$ \\
\hline 5-fold & $1600(1)$ & $\begin{array}{c}1567 \\
(0.979)\end{array}$ & $\begin{array}{c}1559 \\
(0.974)\end{array}$ & $\begin{array}{c}1538 \\
(0.961)\end{array}$ \\
\hline 4-fold & $\begin{array}{c}1586 \\
(0.991)\end{array}$ & $\begin{array}{c}1555 \\
(0.972)\end{array}$ & $\begin{array}{c}1553 \\
(0.971)\end{array}$ & $\begin{array}{c}1528 \\
(0.955)\end{array}$ \\
\hline 3-fold & $\begin{array}{c}1531 \\
(0.957)\end{array}$ & $\begin{array}{c}1539 \\
(0.962)\end{array}$ & $\begin{array}{c}1524 \\
(0.953)\end{array}$ & $\begin{array}{l}1456 \\
(0.91)\end{array}$ \\
\hline 2-fold & $\begin{array}{l}1424 \\
(0.89)\end{array}$ & $1372(0.9)$ & $\begin{array}{c}1404 \\
(0.878)\end{array}$ & $\begin{array}{c}1304 \\
(0.815)\end{array}$ \\
\hline
\end{tabular}

Tabel 5 Hasil pengukuran false positive rate

\begin{tabular}{ccccc}
\hline $\begin{array}{c}\text { Nilai } \\
k \text {-fold }\end{array}$ & $\begin{array}{c}P C A, \\
k N N\end{array}$ & $\begin{array}{c}P C A- \\
\text { LDA, } \\
k N N\end{array}$ & $\begin{array}{c}P C A, \\
S V M\end{array}$ & $\begin{array}{c}P C A- \\
\text { LDA } \\
S V M\end{array}$ \\
\hline 10-fold & $0(0)$ & $22(0.014)$ & $0(0)$ & $29(0.018)$ \\
8-fold & $9(0.06)$ & $33(0.021)$ & $0(0)$ & $31(0.019)$ \\
6-fold & $0(0)$ & $26(0.016)$ & $17(0.011)$ & $53(0.033)$ \\
5-fold & $0(0)$ & $33(0.021)$ & $41(0.026)$ & $62(0.039)$ \\
4-fold & $14(0.009)$ & $45(0.028)$ & $47(0.029)$ & $72(0.045)$ \\
3-fold & $69(0.043)$ & $61(0.038)$ & $76(0.048)$ & $144(0.09)$ \\
2-fold & $176(0.11)$ & $228(0.143)$ & $196(0.123)$ & $296(0.185)$
\end{tabular}

Hampir sama seperti program pengambilan dataset wajah, ketika frame gambar yang ditampilkan berhasil menemukan wajah manusia berdasarkan file XML Haar Cascade, maka program pengenalan wajah ini akan berusaha menemukan wajah. Perbedaannya, program juga sekaligus memiliki tugas tambahan yaitu menebak siapa orang yang berada di dalam frame gambar tersebut. Jika wajah yang ditangkap kamera dianggap cocok dengan sampel true positive yang berasal dari file pickle berisi informasi terenkripsi berupa byte stream, maka program pengenalan wajah ini akan menggerakkan solenoid kunci pintu melalui perintah GPIO dan membukakan akses pintu. Selain kondisi tersebut, program tidak akan memerintahkan GPIO untuk mengaktifkan rangkaian solenoid. Tampilan program aplikasi saat menangkap wajah dapat dilihat pada gambar 5 .

\section{Hasil dan Diskusi}

Pengujian waktu pengenalan wajah dilakukan menganalisis metode pengenalan fitur, classifier, dan validasi dataset yang terbaik untuk diimplementasikan di dalam sistem penguncian pintu berbasis pengenalan wajah. Hasil-hasil pengujian di bawah ini adalah berdasarkan jumlah dataset yang digunakan yaitu berjumlah 1640 (40 gambar x 41 orang) dengan ukuran gambarnya masingmasing sekitar $75 \times 100$ piksel. Pengujian ini dilakukan sebanyak tiga kali setiap fold lalu ketiga hasil tersebut dirata-rata. Perangkat tersebut adalah Raspberry Pi 3 Model B. Pengujian ini menunjukkan bagaimana performa Raspberry Pi 3 Model B yang akan digunakan sebagai perangkat keras utama dalam sistem penguncian pintu ini bekerja dalam melakukan validasi dataset gambar wajah.

Pengujian pada dalam penelitian ini adalah pengujian yang dapat diukur bersifat statistika, antara lain detection rate, tingkat akurasi validasi, waktu validasi, dan waktu pengenalan wajah.

\section{a. Detection Rate}

Pengujian detection rate dilakukan dengan pencocokan gambar wajah dari dataset wajah. Hasil-hasil pengujian di bawah ini adalah berdasarkan jumlah dataset yang digunakan yaitu berjumlah 1640 (40 gambar x 1 sampel true positive, 40 gambar x 40 sampel true negative) dengan ukuran gambarnya masing-masing sekitar 75x100 piksel. Pengujian ini dilakukan sebanyak tiga kali setiap fold lalu ketiga hasil tersebut dirata-rata. Pengujian ini bertujuan untuk mengetahui hasil system testing yang diselesaikan oleh $\mathrm{k}$-fold cross validation pada saat proses training. Berdasarkan jenisnya, pengujian detection rate ini dibagi menjadi 4 , di antaranya:

1) Sensitivitas

2) Spesifisitas

3) False possitive rate

4) False negative rate

\section{b. Sensitivitas}

Untuk pengenalan wajah, sensitivitas menyatakan probabilitas sebuah wajah yang dideteksi bersifat cocok dengan gambaran wajah lain dari wajah yang sama. Semakin tinggi nilai sensitivitas maka semakin baik performa sistem dalam melakukan pencocokan wajah seseorang dengan wajah orang lain. Sebaliknya, semakin rendah nilai sensitivitas maka semakin buruk performa sistem dalam pencocokan wajah seseorang dengan wajah orang lain, sehingga memungkinkan terjadinya kesalahan dalam melakukan pengenalan wajah. Hasil pengukuran sensitivitas yang dibagi berdasarkan nilai $\mathrm{k}$-fold untuk jumlah pengetesan sampel true positive sejumlah 40 gambar 
dapat dilihat di dalam Tabel 3 di bawah ini.

Hasil pengujian menunjukkan setiap algoritme yang diuji dengan nilai $\mathrm{K}$-fold di atas 8 sudah memiliki sensitivitas pengenalan wajah yang sangat bak mencapai $100 \%$ sesuai dengan jumlah sampel yang diberikan. Ketika jumlah K-fold dikurangi terlihat bahwa kemampuan sensitivitas pengenalan wajah juga menurun.

\section{c. Spesifisitas}

Untuk pengenalan wajah, spesifisitas menyatakan probabilitas sebuah wajah yang dideteksi bersifat tidak cocok dengan gambaran wajah lain dari wajah yang berbeda. Semakin tinggi nilai spesifisitas maka semakin baik performa sistem dalam melakukan pencocokan wajah seseorang dengan wajah orang lain. Sebaliknya, semakin rendah nilai spesifisitas maka semakin buruk performa sistem dalam pencocokan wajah seseorang dengan wajah orang lain, sehingga memungkinkan terjadinya kesalahan dalam melakukan pengenalan wajah. Hasil pengukuran spesifisitas yang dibagi berdasarkan nilai k-fold untuk jumlah pengetesan sampel true negative sejumlah 1600 gambar dapat dilihat di pada Tabel 4. Hasil pengujian tersebut menunjukkan bahwa algoritme PCA dan SVM serta algoritme PCA dan K-NN mendapat hasil terbaik dibandingkan dengan algoritme lainnya.

\section{d. False Positive Rate}

Untuk pengenalan wajah, false positive rate menyatakan probabilitas sebuah wajah yang dideteksi bersifat cocok dengan gambaran wajah lain dari wajah yang berbeda. Semakin tinggi nilai false positive rate maka semakin buruk performa sistem dalam melakukan pencocokan wajah seseorang dengan wajah orang lain, sehingga memungkinkan terjadinya kesalahan dalam melakukan pengenalan wajah. Sebaliknya, semakin rendah nilai false positive rate maka semakin baik performa sistem dalam pencocokan wajah seseorang dengan wajah orang lain. Hasil pengukuran false positive rate yang dibagi berdasarkan nilai $\mathrm{k}$-fold untuk jumlah pengetesan sampel true negative sejumlah 1600 gambar dapat dilihat di dalam Tabel 5. Hasil pengujian menunjukkan bahwa algoritme PCA \& K-NN mencacat hasil false positive rate terendah dibandingkan dengan algoritme lainnya.

\section{e. False Negative Rate}

Untuk pengenalan wajah, false negative rate menyatakan probabilitas sebuah wajah yang dideteksi bersifat tidak cocok dengan gambaran wajah lain dari wajah yang sama. Semakin tinggi nilai false negative rate maka semakin buruk performa sistem dalam melakukan pencocokan wajah seseorang dengan wajah orang lain, sehingga memungkinkan terjadinya kesalahan dalam melakukan pengenalan wajah. Sebaliknya, semakin rendah nilai false negative rate maka semakin baik performa sistem dalam pencocokan wajah seseorang dengan wajah orang lain. Hasil pengukuran false negative rate yang dibagi berdasarkan nilai $\mathrm{k}$-fold untuk jumlah pengetesan sampel true positive sejumlah 40 gambar dapat dilihat di dalam Tabel 6 . Hasil pengujian menunjukkan bahwa nilai false negative rate terendah dimiliki algoritme PCA \& $\mathrm{k}-\mathrm{NN}$ dan PCA \& LDA K-NN. Hasil pengujian menunjukkan kedua algoritme gabungan tersebut memiliki nilai identik yang sama persis.
Tabel 6 Hasil pengukuran false negative rate

\begin{tabular}{|c|c|c|c|c|}
\hline $\begin{array}{l}\text { Nilai } \\
\text { k-fold }\end{array}$ & $\begin{array}{l}P C A, \\
k N N\end{array}$ & $\begin{array}{c}\text { PCA-LDA, } \\
k N N\end{array}$ & $\begin{array}{l}P C A, \\
S V M\end{array}$ & $\begin{array}{c}\text { PCA-LDA, } \\
\text { SVM }\end{array}$ \\
\hline $\begin{array}{l}10- \\
\text { fold }\end{array}$ & $0(0)$ & $0(0)$ & $0(0)$ & $0(0)$ \\
\hline 8 -fold & $0(0)$ & $0(0)$ & $0(0)$ & $0(0)$ \\
\hline 6-fold & $0(0)$ & $0(0)$ & $0(0)$ & $1(0.025)$ \\
\hline 5-fold & $0(0)$ & $0(0)$ & $\begin{array}{c}1 \\
(0.025)\end{array}$ & $1(0.025)$ \\
\hline 4-fold & $\begin{array}{c}1 \\
(0.025)\end{array}$ & $1(0.025)$ & $\begin{array}{c}1 \\
(0.025)\end{array}$ & $1(0.025)$ \\
\hline 3-fold & $\begin{array}{c}1 \\
(0.025)\end{array}$ & $1(0.025)$ & $2(0.05)$ & $3(0.075)$ \\
\hline 2-fold & $4(0.1)$ & $4(0.1)$ & $4(0.1)$ & $4(0.1)$ \\
\hline
\end{tabular}

Tabel 7 Rata-rata waktu pengenalan wajah raspberry Pi 3

\begin{tabular}{ccccc}
\hline $\begin{array}{c}\text { Nilai } \\
\text { k-fold }\end{array}$ & $\begin{array}{l}\text { PCA, } \\
\mathrm{kNN}\end{array}$ & $\begin{array}{c}\text { PCA- } \\
\text { LDA, } \\
\mathrm{kNN}\end{array}$ & $\begin{array}{c}\text { PCA, } \\
\text { SVM }\end{array}$ & $\begin{array}{c}\text { PCA- } \\
\text { LDA, } \\
\text { SVM }\end{array}$ \\
\hline 10-fold & 0.121 & 0.122 & 0.127 & 0.121 \\
8-fold & 0.126 & 0.129 & 0.125 & 0.122 \\
6-fold & 0.132 & 0.127 & 0.133 & 0.109 \\
5-fold & 0.121 & 0.120 & 0.122 & 0.121 \\
4-fold & 0.111 & 0.116 & 0.117 & 0.126 \\
3-fold & 0.125 & 0.128 & 0.122 & 0.128 \\
2-fold & 0.129 & 0.125 & 0.123 & 0.124 \\
\hline
\end{tabular}

Melalui data yang disajikan di dalam Tabel 7, menunjukkan waktu yang dibutuhkan Raspberry Pi 3 Model B dalam melakukan proses pengenalan wajah pada masing-masing metode berkisar antara 0.109 sampai dengan 0.133 detik. Hasil ini sifatnya identik sehingga tidak dapat digunakan sebagai parameter untuk membandingkan masing-masing metode. Akan tetapi, ada yang dapat disimpulkan dari hasil tersebut, yaitu selama aplikasi pengenalan wajah berjalan, Raspberry Pi 3 Model B hanya mampu menghasilkan sekitar 8 hingga 9 frame per detik, dari target 30 frame per detik. Angka-angka yang dihasilkan di dalam Tabel 3 lebih dipengaruhi oleh performa komputasi Raspberry Pi 3 Model B yang cukup baik. Hasil pengukuran rata-rata waktu pengenalan wajah dapat dilihat di dalam Tabel 7.

Pengujian akurasi validasi membantu menganalisis metode training dataset yang paling baik untuk diimplementasikan di dalam sistem penguncian pintu berbasis pengenalan wajah. Hasil-hasil pengujian di bawah ini adalah berdasarkan jumlah dataset yang digunakan yaitu berjumlah 1640 (40 gambar x 41 orang) dengan ukuran gambarnya masing-masing sekitar 75x100 piksel. Pengujian ini dilakukan sebanyak tiga kali setiap fold lalu ketiga hasil tersebut dirata-rata. Berdasarkan jenisnya, pengujian akurasi validasi ini dibagi menjadi empat, di antaranya:

1) Metode Eigenfaces/PCA dan K-Nearest Neighbor (K-NN)

2) Metode hybrid PCA-LDA dan K-NN

3) Metode Eigenfaces/PCA dan Support Vector Machine (SVM)

4) Metode hybrid PCA-LDA dan SVM 


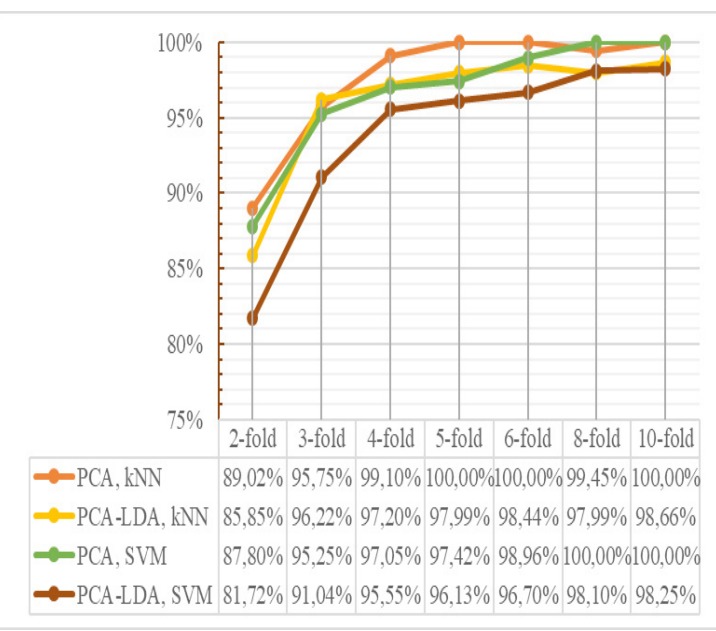

Gambar 6. Hasil Uji perbandingan metode yang digunakan

Berdasarkan hasil dari grafik perbandingan pada Gambar 6, terlihat bahwa jika dilihat dari hasil akurasi validasinya secara keseluruhan, metode Eigenfaces atau PCA menghasilkan nilai rata-rata yang lebih baik dibandingkan metode bybrid Eigen-Fisherfaces atau PCALDA. Untuk penggunaan classifiernya, hasil akurasi validasi yang lebih baik dihasilkan oleh metode klasifikasi k-NN dibandingkan dengan metode klasifikasi SVM. Ciri khas dari metode klasifikasi SVM yang dirasa menjadi hambatan adalah implementasi byperplane [17]. Objek yang digunakan di dalam sistem ini memiliki jumlah minimal 41 buah, sehingga dengan konsep byperplane yang dirancang untuk melakukan klasifikasi sebanyak 2 class tersebut SVM tidak mampu meraih nilai akurasi sebaik metode k-nearest neighbor.

\section{Kesimpulan}

Berdasarkan hasil penelitian yang telah dibahas dapat diambil kesimpulan bahwa metode machine learning yang paling baik untuk implementasi sistem penguncian pintu ini adalah menggunakan metode pengenalan fitur bybrid Eigen-Fisherfaces (PCA-LDA) dan metode classifier k-nearest neighbor. Kesimpulan ini diambil dengan melihat rasio performa berdasarkan durasi waktu training dan akurasi validasi dengan jumlah fold paling sedikit. Akurasi mendekati $90 \%$ dicapai dengan 2 fold, dan 4 fold dapat dicapai akurasi mendekati $100 \%$.

Metode machine learning dan jumlah fold yang digunakan pada proses validasi tidak mempengaruhi performa berdasarkan durasi waktu pengenalan wajah. Selain itu nilai $\mathrm{k}$ yang lebih besar dalam melakukan validasi menggunakan k-fold cross validation akan menghasilkan akurasi yang lebih baik, disebabkan karena semakin besar nilai $\mathrm{k}$ dalam jumlah dataset yang sama maka jumlah data yang dapat digunakan untuk training akan semakin banyak.

Hasil penelitian ini juga menunjukkan bahwa perangkat Mikrokontroler Raspberry Pi 3 Model B yang menjadi perangkat keras utama dalam sistem ini memiliki performa yang cukup baik dalam hal pengenalan wajah. Hal ini dibukti melalui serangkai hasil uji coba yang telah dilakukan perangkat tersebut berhasil mengenali wajah dengan baik dengan rasio sukses 81\%-100\%

\section{Daftar Pustaka}

[1] K. Cherry, "Biometrics: An In Depth Examination," dalam SANS Institute InfoSec Reading Room, Chicago, Sans Institute, p. 11, 2014.

[2] K. Delac, M. Grgic dan S. Grgic, "Independent Comparative Study of PCA, ICA, and LDA on the FERET Data Set," Wiley Periodicals, vol. 15, pp. 252260, 2015.

[3] K. Ignivov dan V. Rans, "Biometrics: Personal Identification in Networked Society," International Journal of biometrics, pp. 150-158, 2016.

[4] A. K. Jain, A. Ross dan S. Prabhakar, "An Introduction to Biometric Recognition," IEEE Transactions on Circuits and Systems for Video Technology, vol. 14, no. 1, pp. 4-20, 2014.

[5] S. Zhang dan M. Turk, "Eigenfaces," Scholarpedia, vol. 3, no. 9, p. 4244, 2008.

[6] A. Martinez, "Fisherfaces," Scholarpedia, vol. 6, no. 2, p. 4282, 2011

[7] Raspberry, "Raspberry Pi FAQs - Frequently Asked Questions,” Raspberry, [Online]. Available: https:/ / www.raspberrypi.org/ help/faqs/\#powerReqs. [Diakses March 2017].

[8] Y. Januzaj, A. Luma, Y. Januzaj dan V. Januzaj, "Real Time Access Control Based on Face Recognition," International Conference on Network Security \& Computer Science, pp. 7-12, 2015.

[9] L.-H. Chan, S.-H. Salleh dan C.-M. Ting, "PCA, LDA and Neural Network for Face," ICIEA IEEE, pp. 1256-1259, 2016.

[10] A. R. S. Siswanto, A. S. Nugroho dan M. Galinium, "Implementation of Face Recognition Algorithm for Biometrics Based Time Attendance System,” 2014.

[11] R. Brunelli, Template Matching Techniques in Computer Vision: Theory and Practice, Wiley, 2009.

[12] M. Sirovich dan A. Kirb, "Reviewing Eigenfaces for Recognition," Journal of Neuroscience, vol. III, no. 1, pp. 71-86, 2011.

[13] P. N. Belhumeur, J. P. Hespanha dan D. J. Kriegman, "Eigenfaces vs. Fisherfaces: Recognition Using Class-Specific Linear Projection," IEEE Trans. Pattern Analysis and Machine Intelligence, Vol. 19, No. 7, pp. 711-720, 18 April 1997.

[14] Sugiyono, Metode Penelitian Kuantitatif Kualitatif dan R\&D, Bandung: Penerbit Alfabeta, 2015.

[15] P. Refaeilzadeh, L. Tang dan H. Liu, "CrossValidation," 611 2008. [Online]. Available: http:// leitang.net/papers/ency-cross-validation.pdf. [Diakses 174 2017].

[16] M. Faundez-Zanuy, "Biometric Security Technology," IEEE A\&E Systems Magazine Vol. 21, No. 6, pp. 15-26, 2014.

[17] R. Budiarto, "Manajemen Risiko Keamanan Sistem Informasi Menggunakan Metode FMEA dan ISO 27001 pada Organisasi XYZ," Journal Of Computer Engineering System And Science, vol. II, no. 2, pp. 105115, 2017. 